\title{
Yorùbá Thoughts and Beliefs in Child Birth and Child Moral Upbringing: A Cultural Perspective
}

\author{
Omọobọlá Agnes Aládésanmí, Ìbùkún Bọláńlé Ògúnjìnmí \\ Department of Linguistics and Nigerian Languages, Ekiti State University, Ado-Ekiti, Ekiti State, Nigeria \\ Email: bolaaladesanmi@gmail.com,ogunjinmibolanle@gmail.com
}

How to cite this paper: Aládésanmí, O. A. \& Òúnjinmí, I. B. (2019). Yorủbá Thoughts and Beliefs in Child Birth and Child Moral Upbringing: A Cultural Perspective. $A d$ vances in Applied Sociology, 9, 569-585. https://doi.org/10.4236/aasoci.2019.912041

Received: November 15, 2019

Accepted: December 28, 2019

Published: December 31, 2019

Copyright $\odot 2019$ by author(s) and Scientific Research Publishing Inc. This work is licensed under the Creative Commons Attribution International License (CC BY 4.0).

http://creativecommons.org/licenses/by/4.0/ (c) (i) Open Access

\begin{abstract}
Yoruba thoughts and beliefs in childbirth and childmoral upbringing as expressed in Yoruba philosophy and culture are the focus of this paper. The paper pays considerable attention to the prominent position children occupied in the thoughts and beliefs of the Yoruba', this we attributed to why they take absolute care of their children. Some of the findings of this paper is that the main purpose why people of Yorubá extraction venture and spend physically, economically and emotionally on marriage is to have morally and economically formidable children. We show that according to the dictates of Yorubá culture, marriage precedes pregnancy, then, tending of pregnancy, child birth, and moral upbringing. The Yoruba also believe that a child not properly brought up will certainly become social destitute in later years when suchis supposed to be productive. It is also believed that, parents who are survived by culturally, economically and morally acceptable children in the society that have acceptable children. The contemporary Yoruba society must follow suit by making well brought up children a priority as the case is in the traditional Yorubá society that is characterized with largely peaceful co-existence and tranquility, free of bastards and children without paternal and maternal upbringing, owing to the fact that both parents have distinct roles to play in the wellbeing of children in a family which is the pillar of a workable society.
\end{abstract}

\section{Keywords}

Culture, Thoughts and Beliefs, Philosophy, Children, Society

\section{Introduction}

Many scholars have carried out researches on different aspects of Yorubá cultures such as chieftaincy, marriage, naming, burial, economic guild, house warming among others. (Adéoyè, 1979) for instance researched into diverse cul- 
tures of the Yoruba society where he explained in detail the dictates of each of these cultures ranging from marriage, naming ceremony and rites, burial, house worming, etc. (Falola, 2001) also examined the traditional institution of the Yorubá. He paid considerable attention to Yorubá culture on coronation of kings, their roles in the traditional Yorubá society and the Yorùbá culture on chieftaincy affairs. (Àlàbí 2006) in Fálolá and Genova (ed), The Yorủbá in Transition equally researched about "Law Making in Pre-Colonia Yorubá-land" where he discussed the roles of kings and chiefs in the traditional Yoruba society in accordance with the dictates of their culture. (Dáramọlá \& Jéjé, 1967), (Fádípè, 1970) and (Olábímtán, 1987) on the other hand probed into the economic aspects of the Yoruba society. Of particular importance is their analysis of the economic guild in pre-colonial Yoruba society where they argued that the Yoruba society has a structured and economically viable structure before the advent of slave trade and Westernized civilization.

Some scholars equally analyzed Yorùbá novels like that of D.O. Fágúnwà in identifying different Yorubá philosophical beliefs as depicted in the literary works of the writer. (Ogúnsínà, 2009) researched into the usefulness of Yorubá philosophy in Fágúnwàs novels. (Ògúnsínà, 2006) also examined Yorủbá philosophy in the naming of domestic animals where he explained different traditional beliefs associated with such names before they are adopted for domestic animals.

(Táiwo, 2014) on the other hand researched the philosophical beliefs enumerated in the songs of Saheed Osùpá, where she probed into the Yorùbá cultures the artist sang about with marriage custom and children moral upbringing. (Aládésanmí, 2012) also x-rayed the type of relationship that exists between Yorubá philosophy and literature. She delved into how philosophy is expressed in novels like OmoT.ékùn Bí, Àdìtú Olódùmarè Orilawè Ádigún and ÈdáOmo Ooduà She itemized different philosophical beliefs that are pivotal to the successful co-existence of the Yoruba society as represented in the four novels. She equally established that truly, the Yorubá have their own philosophy as opposed to arguments of some European scholars who believe and teach that there is no philosophy in the Yorubá society. (Aládésanmí, 2012) established that philosophy exists in the Yorubá society as evident in oral poetry like folktales, proverbs, praise poetry, songs, etc. She also explained that Yorubá philosophy is different from those of other cultures, continents and climes, most especially the Europeans. It may not be widespread due to the fact that Western Education got rather late to the Yoruba society. This paper is also a testament to the fact that there is no part of the Yorubá culture and lifestyle that does not have a philosophical belief backing it.

Yorubá thoughts and beliefs on the importance of child birth and child moral upbringing is our focus with the aid of philosophy in this paper. The choice is deliberate in other to have a firsthand knowledge of how important children are in the belief system of the Yoruba as evident in their culture. The reason is that many undesirable happenings have bedazzled the contemporary Yorubá society, 
which makes it evident that the root was from the family which is regarded as important and one of the bases for a better society. The study adopted the ethnographic approach of qualitative research type for the analysis of the paper. This we domesticated to have an illuminative account of the social life of the Yorubá society as depicted in their culture and the philosophy behind the particular social system based on multiple detailed observation of what they do in their social setting that is observed in their thoughts and beliefs on child birth, child upbringing and child education.

\section{Yorùbá Culture}

Scholars in the field of literature and culture, like (Devito, 2000), (Ilésanmí, 2004), (Àjayí, 2005), (İsọlá, 2010) and (Òjó, 2013), have stated that culture is the belief, thought and art of a group of people who are a cluster of a town or country. Parts of the culture that characterize such people are their occupation, mode of dressing and the food they eat, the way they celebrate etc.

Different scholars have diverse views to what culture is or what it should be. (Obáfémi 2012: 8) opined that:

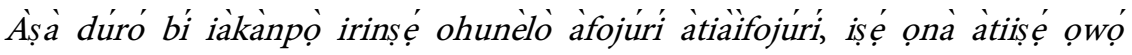
àwonirankan tó fi mọ ìmọ tí à wonènìyàirannà tikó jộinọpọ ơdún.

Culture stands as a combined force of material and immaterial things such as works of art and vocational activities of a group of people, including the knowledge they processed for years.

Implicatively, culture stands as instruments that could be material or immaterial of a group of people. It is always evident in the knowledge they gather through their life experiences for years. It is in a society that we gather experiences and acts that are regarded as acceptable, which summed up to become their culture.

(İsọlá, 2010: 10) explained in detail the argument of Obáfémi thus:

There are tangible cultures like handcrafts, paintings, drawings, and museum sights. Intangible ones that cannot be seen or touched like language, oral poetry, aesthetics, traditional dances, festivals, traditional medicines, style of cooking, artifacts and other culturally inclined treasures of yesteryears.

(İsọlá, 2010) divides culture into two parts, the first is tangible culture that can be seen and touched while the second is the intangible culture which can only be felt. He states further that the tangible cultures are the ones the forefathers gave as traditions through oral (mouth to mouth) cultural transmission, example of such are embedded in proverbs, legends, myths and other forms of oral performances. Sadly, the intangible cultures are getting little or no attention and daily on the verge of extinction, a development that requires serious attention. Examples of such are taboos, greeting forms and moral teachings. Therefore, this set of intangible cultures deserves to be protected from going into extinction. In a nutshell, cultures of distinct group of people such as their language, belief, mode of dressing, food, religion, economy, political system and other things that de- 
fine them are their culture and identity. From the foregoing, it is evident that culture is the distinct wisdom, experiences, knowledge, understanding and beliefs people of a particular society are surrounded with as reflection of their society.

In the Yoruba society, it is observed that from conception (right from the womb), Yorubá children are introduced into the world of taking instructions, corrections and distinctive acculturation. This is demonstrated when a pregnant Yoruba woman is seen tapping on her stomach when she feels the position of the fetus is to her discomfort. Without any oral form of instruction, such baby-in-making takes to correction and makes a comfortable adjustment and posture for the peace and comfort of the mother. In contemporary times, children that could have been given birth to coming with the legs which the Yoruba regard as "ige" are fondly corrected at the hospital to come through the normal process of child birth (coming out with the head). Having such children come to the world through the legs always put the life of the mother at risk, hence the popular oríkì for such children “... ọdájú omo, omọ bí iyá bá le kú kó kú ...” (... a cruel child who does not care if the mother dies in the process of giving birth ...). With the advancement in medicine, science and technology, such children can be successfully turned and the delivery seamless or less risky for the mother. Other examples abound in the type of instruction given to pregnant women not to walk about in the hot afternoon or at night. This is to ensure the life of the baby is not at risk of been possessed by kindred spirits. The mother can also be at the mercies of kidnappers and men of the underworld who use pregnant women for human sacrifices and rituals. The father is also instructed to always take caution especially if he is a hunter among others. All this are carefully outlined in the Yoruba culture to ensure that the father, mother and the baby are in good and safe condition. The successful moral upbringing of a child in the Yoruba society also rest largely on the ability of both parents to be physically, morally and economically viable to take full responsibly on their child. The absence of either of them could make the life of the child miserable and most times have adverse effect on their future.

It is to be noted that from the very first day of birth of a Yoruba child, they started hearing poetry and songs meant for their delight and moral education. It is mostly from the grandmother or older women welcoming the new born by chanting the family oriki and lullabies. During childhood, a proper and effective mode of socialization is ensured through the use of songs or other forms of literature. (İsọlá, 2010: 2) pointed that such songs do have essential information meant to ensure a continuity of traditions and customs packed into children's literature. Information about plant and animal life, insightful remarks about the nature of the language, mnemonics for counting and a lot of moral instructions woven into poems, stories, rhymes, lullabies and children songs. When lullabies are sung for children, the baby is not expected to understand the meaning of the words, but the rhythm of the songs and the movement of the singer helped ma- 
jorly to lull the child to sleep. As the child grows, a notable improvement is made on such literature and medium of instruction to accommodate more information about the working of their society. Such information are composed and thought to children to impart positively into them either morally, academically, spiritually or to give specific formative instructions. However, of great importance are the aspects of presentation which in most cases are presented in rhymes, folktales and lures, mode of presentation or melodies of songs, fully loaded with messages with either moral, cultural, spiritual or of academic intents. The period or time of use of each song dictates the choice of song to be used and how it is used, etc.

From the point of view of the Yoruba society about proper upbringing of children, one could deduce that their ways of child birth, upbringing and education are also part of their culture as will be discussed further in other parts of this paper.

\section{Philosophy in the Yorùbá Society}

Philosophy is the concept that plays a pivotal role in the improved living condition of the human race. This is achieved through probing and researching into things that bother on their culture, arts and beliefs, with the aim of engendering development to the human race. Many scholars have researched into philosophy in the Yorubá society. Scholars like (Ògúnsínà, 2006), (Oládiípọ, 2005), (Aládésanmí, 2012), (Oyèwálé, 2014) and (Táínò, 2014). They established that philosophy truly exist in the Yorubá society. (Oládiípọ, 2005: 2) explained that:

The term "Yoruba' Philosophy" in this context should be understood to mean not simply a body of ideas, collective and individual in term of which the world and the twist and turns of human experience are explained, but also a system of values and attitude which guides lifestyles and conduct. This Yoruba' Philosophy not only includes the ideas of the Yoruba' on life, existence, reason, knowledge and so on, as embodied in the language and oral traditions of the people, and as exhibited in their social practice. It also includes the exploration of constriction of these ideas in the works of Yoriba writers and philosophy.

Oládipo's argument is that philosophy exists in the sub-conscious mindof the Yorubá people as shown in their thoughts, language use and way of life. He insisted that it is also evident in their method of communication, community life, language formation, literature and other things inherent in their society. Philosophy is what Dáramọlá and Jejé (1975) called thoughts and beliefs of the Yorùbá about things they believe in. This is demonstrated in their belief in Elédumarè (God), arts and culture and in other aesthetics. (Ògúnsínà, 2006: 106) also describe philosophy as: "ẹkọ́ tó ń șeayẹwò fínnífínní àtiàwojinlẹ ìtumọ, èrèdí àwọnnnkan tó șepàtài nínú ìronú, ìgbàgbọ àtisíseọmọnìyàn”. (Philosophy is the discipline that probes and research into meanings, causes of important happenings in human thoughts, beliefs and in their deeds. Philosophy of the Yoruba encompasses their feelings, views about life and description of things that reflect 
their existence, of which child birth and moral upbringing are paramount.

\section{Yorùbá Thoughts and Beliefs in Child Birth and Child Moral Upbringing}

Yorubá people believe giving birth to children is one of the most important things they live for; they believe children are the most important heritage and legacy to leave behind after death. That is why they do everything possible to have morally brought up and viable children. It is also a belief in the Yoruba society that whoever does not give birth to children has no sustainable legacy. As a result of the place of prominence children occupy in the belief system of the Yorubá, it is naturally by the way of procreation impossible to have children without sexual relationship between a man and a woman, therefore, there must be a sexual relationship between a couple before pregnancy can be achieved and then, child birth. Yorubá culture does not permit pregnancy or childbirth before marriage. What the Yoruba culture permits is having a well founded and structured home before pregnancy and eventual child birth and upbringing. A man or woman of marriageable age that refuses to get married does not always get the approval of people of the Yorubá society. Instead, they make corrective mockery of such individuals until the needful is done.

Scholars on Yorubá culture have worked on Yorubá marriage custom. Scholars like (Fádípè, 1970), (Dáramólá \& Jéjé, 1975), (Adéoyè, 1979), (Ọlábímtan, 1979), (Adébọwálé, 1999), (Fálolá, 2001), (Abímbọ́lá, 2006), (Òứnsínà, 2006), (Olátéjú, 2016), (Táiwò, 2017) and (Oláíyá, 2017) all explained that for any matured person in the traditional Yorubá society to enjoy a generally acceptable pattern of life is inherent in love and having a home which is preceded by marriage. (Oyèwálé, 2016) established that marriage custom is a very important part of Yoribá culture. He opined that Yoruba philosophy gathered from the experiences in the society necessitated the place of prominence marriage occupies in their culture.

(Fádípè, 1970) also explained that marriage in the Yorùbá traditional society is not just between the male and female that are to get married. There are several processes involved before it can be acceptable. The reason is that the marriage custom is regarded so imperative and that, it is only through the means of marriage that it is acceptable to the Yoruba society for one to have children and a sustainable tomorrow. (Olábímtán, 1987) also posited that in the traditional Yorubá society, it is a must for a man to marry and for the woman to be joined in marriage to a man; it is only through the mutual relationship that exists in marriage that the Yoruba believe could produce tenable and legitimate children. Apart from that, a good and excellent inter-relationship have to exist in a home before the home is regarded culturally healthy to bread good children. The belief is that both the husband and the wife have distinct roles to play for the wellness of a family and by extension the society. The traditional Yoruba society believes absolutely in the adage that "àgbájoowọ la fi ń sọyà" in togetherness we stand. It is culturally impossible for a man to have children on his own without inter- 
course with his wife in marriage, while it is not culturally permissible also for a woman to conceive and have children without sexual intercourse with her husband in marriage. Though, the tide is changing in the contemporary Yorubá society, science and technology have improved greatly which have caused a considerable change to the process of child bearing in the Yoruba society and the world at large.

Apart from that, sex, pregnancy and child bearing do not precede marriage in the philosophy of the Yorubá (Fádípè, 1970), and (Dáramólá \& Jéjé, 1975). The Yorubá society does not permit sexual intercourse between a male and a female before marriage, marriage is always the vehicle that brings about peaceful family co-existence, sex, childbirth, child upbringing, child education and a peaceful society. Child bearing and moral upbringing in the traditional Yoruba society have acceptable patterns and processes which must be followed, failure to comply with the dictates of marriage custom cannot enjoy the nod of acceptance of the Yorubá society. Sex, child bearing and child moral upbringing do not happen in the traditional Yorubá society in an unguided manner.

\section{Yorùbá Thoughts and Beliefs in Child Birth and Child Moral Upbringing: A Cultural Analysis}

The Yoruba believe that having children is of a paramount issue in marriage. (Oyèwálé, 2016) established that if there are other reasons Yorubá people ventures into marriage, such reasons are mere additions. With this argument, it shows distinctively that the Yorubá place so much of premium on having children, it is also an integral part of the Yoruba culture. It is a belief of the Yorubá that there are no other luxuries of life that can be compared with having children. That is the basis of the adage in Yorubá that "omobonilárajuaso lọ" (having children is like having a covering cloth). Immediately a newlywed wife is settled in her matrimonial home in Yorubá society, the prayer of both families is for her to start having children. Once it is getting to five months after marriage, and there is no conception, they begin to ask questions from the husband and the wife on the possible causes of the delay. The causes could come from either the husband or the wife, and it could be a collective issue from the two of them. If the couples do not have tenable reasons for the delay, they begin to give the wife concoctions that could aid speedy conception. Once the wife has conceives, family members begin to make different consultations to ensure that the pregnancy gets to fruition without any hitch, especially if the woman had had issues before conception like miscarriages.

All she would be given at the first three months of conception are herbal medicines that would make the fetus developed very perfectly and to forestall possible hitch or loss of the pregnancy. Other traditional methods the Yorubá employ at the stage of pregnancy are: oyúndidè (use of traditional medicine to conceal the pregnancy from the wicked people of the world who could harm the pregnancy), giving of precautionary instructions to the pregnant woman like avoid- 
ance of certain delicacies and fruits (Ọpádọtun, 1998). The Yorùbá philosophy that backs this step is to keep the pregnancy in good shape.

The Yorubá also believe that a pregnant woman must not move about under hot sun or at mid-nights, these times are considered dangerous for movement due to the belief that evil spirits move about searching for hiding places where they can make their abode. If they come in contact with a pregnant woman in such hours, it is believed that they will replace themselves with the fetus and as a result, the woman will give birth to a problematic or spiritually abnormal child. Another belief is that a pregnant woman should not eat okra or snail so that the child will not be drooling saliva while growing up.

It is not just the pregnant woman that is subjected to limitations while in that state; the husband is also subjected to some restrains, especially if he is a hunter. He will be cautioned from killing some kind of animals like pregnant deer. It is widely believed among the Yoruba that such animal possess a kind of magical power to transform and put itself in the state the wife or children of the hunter is at home. The Yoruba thought and belief inherent in this is that if a hunter encounters such animal especially those mating, the hunter must exercise some restrains in shooting at them so he does not regret the action afterwards. It is assumed the wife of the hunter may be having extra marital affair which the mating animals could represent to the hunter. The same belief goes for a hunter whose wife is pregnant, shooting such animal could translate to shooting his pregnant wife in the real sense of things Olajubù (1985). If we put to consideration most of the precautionary measures or instructions given to a pregnant woman, they all emanated from the wealth of experiences of the Yoruba which they gathered from their environment from time to time, this in turn translate to their thoughts and beliefs on issues.

When the pregnancy grows to six months, the type of traditional method of care giving employed in such state are usage of herbal medicine and amulets that will make the pregnancy grow as expected. They also give traditional medicine that will safeguard the fetus from certain sickness that could deform the child after birth. Once the pregnancy reaches the eighth month, they begin to make herbal concoctions that will make delivery easy and hitch free. At the ninth month is when preparation for safe delivery begins. All precaution devices against miscarriage will be removed, while the pregnant woman will be restricted from travelling or moving too far from the house.

At the time of delivery, the eldest wife (ìyálé) of the house or family is always in charge of the delivery of the younger pregnant wife. The service of a traditional birth attendant could also be required if the need arises in case of complications. Once a pregnant woman's water breaks or she sees blood, it is a signal that it is time for delivery. The woman will be taken to a room already prepared for that purpose, she will be asked to lie on her back or to kneel. Once she is delivered of her child, they will await the delivery of the placenta before she can be declared to have safely delivered. It is until then that the news of her delivery will 
be given to her husband and relatives Ọ̀pádọtun (1995) and Ọláiyá (2017).

Relatively warm water is used to wash a new born baby after the umbilical cord has been taken care of. A specially made bathing soap (oșeabùwè), locally made sponge (kànin-kàninibílè) and traditionally made cream (osùn) are used for the first bath of the baby. They ensure the baby is well cleaned to avoid unwarranted body odour which is believed to last a life time if the child is not properly cleaned at the first bath Olájubù (1985) and Oláiyá (2017). Hot water and a thick fabric or towel is also used to clean and press the stomach of the new mother after birth which continues till around two to three weeks after delivery, doing this is believed will melt the clot of blood that would have formed up in her stomach during the process of child birth.

After that, the child will be given the family tribal mark and circumcised either the child is male or female Táiwo (2017). Circumcising a male child in the Yorubá belief system enables his male organ to be more beautiful, active and also helps to do away with possible infection of the cut away part Táíwo (2017). Circumcision of a female child on the other hand is believed to be a compulsion in the Yoruba traditional setting. The philosophical belief that accompanies this is to guide against the child's promiscuous tendencies. The Yoruba belief a female child that is not circumcised will be promiscuous and always show interest in having intercourse Olájubù (1985), Fádípè (1970) and Táíò (2017). As a result, the Yorubá holds circumcision for both male and female children very imperative though the culture is becoming abolished in the contemporary Yoruba society. Many Yorubá speaking states in Nigeria have domesticated girl child circumcision as a criminal offence; this is due to civilization and the imposition of Western culture on the Yoruba culture. Research in medicine has also shown that girl child circumcision is harmful and it is with no benefit. It also proscribes the act as barbaric and full of undesirable consequences like bodily injury to the female sexual organ, and contracting of deadly diseases like the dreaded HIV/AIDS. It can cause drastic reduction in sexual libido in circumcised women which could eventually lead to divorce, stigmatization and death if not well managed. It is also reported that it can cause infant mortality Táíwo (2017), Constitution of the Federal Republic of Nigeria and The Constitution of Ekiti State (2002). Due to the domestication of this medical report, and the overbearing tendencies of the Western culture and civilization, the culture of female circumcision in the Yorubá society is getting jettisoned and relegated daily.

The same is the case with giving children tribal marks, facial marks are majorly given for beautification, tribal and family identification purposes Olájubù (1985). But the culture is no longer in vogue in the contemporary society. There are few or no parents of Yorubá extraction that allow giving of tribal marks to their children again Táiwò (2017). Apart from that, Táíwo (2017) also explained that seven days after delivery of a child is when the child is circumcised and given tribal marks. It is done mainly in the morning. The Yorubá belief that giving tribal marks and circumcision at the early days of child birth will not allow the child feel the pain or inflict injury on the child. They believe that doing it in later 
years could cause bodily injury on the child and her sexual organs. They also believe that it should be done early in the morning when the day is young and the blood is not hot, so as to aid timely stoppage of the blood that will come out of the tribal or circumcision wound.

Another Yoribá philosophical belief associated with giving of tribal marks and circumcision is that a child does not die doing the process (omoki ítowóoníkolàkú) and that any child that dies in the process is not destined to live Táíwo (2017). Before tribal marks and circumcision is done on a child, they will take the child first to an Ifá priest for consultation to have knowledge of the child's destiny and taboos, so that the child's destiny will not be hindered. The Yorubá believe everyone came to the world with destiny, but forgets as they get to the world, the process of getting to know the destiny of every child is done through Ifá consultation. The Yorubá belief in (Ờrúnmilàlériiiipín) the custodian of destiny that he was there when everyone chose the destiny they brought to the world Fádipe (1970), Elébuibon (2005) and Adétugbọ (2001). It is the responsibility of the Ifá priest to appease Òrúnmilà to reveal the destiny of any child brought to him for that purpose, and Ờrúnmilà through citation of the relevant Odù that appears in the process of consultation reveal what the destiny of the child is, with emphasis on things to do and not to do for the fulfillment or realization of the child's destiny.

After circumcision and giving of tribal marks comes the child's naming ceremony. The process of naming a child is in two forms in the traditional Yoruba society. If it is a male child, he will be named on the ninth day after birth due to the nine bones of his ribs. If it's a female child however, she will be named on the seventh day because of the seven bones that makes up the female ribs, while twins are named on the eighth day Olábímtán (1987). The process of naming a child begins right from the day it was realized the mother has conceived, and it could be from the day of birth, Yorubá people do not give names to their children in anyhow. There are some features and requirements the circumstances surrounding the birth or the family must meet before a name can be chosen for such child or the praise name (oriki). The Yoruba thought and belief that go with this is that (ilé là á woká tó soomolórúko)' meaning the event in their environment at the time of birth of such child will determine the kind of name the child will be given. Factors that do influence giving names in the traditional Yoruba society are: family lineage (orúkoidilé), events surrounding the time of the child's birth like the death of the father, grandfather or grandmother goes with the belief in giving names like Babárínsá, İyábọdé, Babátúndé, Babájídé etc. A child can also be named with regards to the family occupation or deity, names associated with family occupation like that of traditional drummers and hunters include: Àyàngbèmí, Àyánsolá, Àyànníyì, Ògúnjinmí, Ògúngbèmí, Ògúnmọlá, Ogúnsolá etc. Names that are associated with family deities are: Orojídé, Sàngójimí, Ẹ̀sùgbèmí, Ọbàyemí, Osóyímiká, ợsunfúnmikẹ, Òrịsásọonà etc. Every Yorubá familyhas deities and gods that they worship, since name is giving main- 
ly for identification purposes, hence Yoruba people give names that shows the religion, strength, exploit and other things they are proud of or known for in their family or linage Olábímtán (1987) and Oláiyá (2017). A child's name could also reflect the economic status, affluence or chieftaincy exploit of the family, example of such names include: Oláyímiká, Oláoyè, Òkikíolá, Akínjidé, Akíntúndé, Akíntóyè, Adéyímiká, Adéoyè, Sóoróyè. More so, names in Yorubá society do have meanings according to the manner of their birth. Names (orúkoàmútọrunwá) like Òjó, Äìná, Táyéwò and Kéhìndé, İgè, ìlọiri and so forth are examples of such names. Yorubá also have names they give to children who they believe reincarnate or who die after birth and come back again (orúkoabíkú). Such children are believed to be possessed and sent from the spirit world to punish their parents and family. Names that reflect Yorubá belief on such children include: Jéáriogbé, Ikúkọyí, İgbẹ́kọyí, Kòsọ́kọ́, Málomọ́ etc.

Immediately the father of a child gives a name to the child, it is the name the father gives to the child that supersedes any other name given by family members, relatives and friends, even the mother. It is the name the father gives that stands. Any alteration renders the child a bastard which the Yoruba culture frowns so much at Oláiyá (2017).

The ingredients the Yoruba use in a typical naming ceremony are always philosophical with distinct meanings, such ingredients include: sugar cane, salt, palm oil, catfish (ejaaborí), water, honey, alligator pepper, kola nut, bitter kola, local gin etc Olábímtán (1987) and Oláiyá (2017). The child will be given to an elderly woman, usually, the eldest wife in the family (İyáálé) while the mother of the child sits by her side, all the naming ingredients will be shown to the child or put in the child's mouth for a taste with (iwúre) prayers that shows the Yorùbá thoughts and beliefs that accompany such ingredients. Sometimes, the ingredients could be given to the mother to eat with the belief that the child will suck same from her mother's breasts, while those present at the ceremony say (Àse!!!) amen to accompany and establish their belief in the efficacy of the prayer and the ingredients.

Johnson (1921) explained that after the prayers, the child will be taken to the entrance of the family house where water will be poured on the roof top for the water to drop on the child with the belief that it is then that the child is confirmed to be part of the family or household. After that, other rituals or family rites which vary from family to family will be performed to prevent the child from premature death and also to be sure the child is not a bastard olaíyá (2017). If the child is from a priest's family, the child will be taken through a special family initiation process called (fifesẹteopọn Ifá) that is; the child's leg will be placed on the Ifá divination tray so as to identify the child with the occupation and the religion of the family. It is on this same naming ceremony day the child's ears will be pierced; either a male or a female child. The Yorubá pierced the ears of both sexes with the belief that any child that is not taken through this process will have impediments in hearing well, and that if a man with hearing 
deficiency pierces the ear of a new born, such child will also have impediments in hearing Ládélé, Oyèbámijí, Oyèdèmí and Olátúnbọsún (2006).

Another Yorubá philosophy that manifests from the Yoruba thoughts and beliefs in child bearing and education is that if by virtue of mistake two youths who are not traditionally joined in marriage, by unchecked friendship, secretly have sexual relationship and that such lead to pregnancy especially when the family of either of them are not giving support or approval of the relationship; The Yorubá believe that since the relationship has led to pregnancy, they must be allowed to become one in marriage and declared husband and wife. This is due to the belief that whoever that has given birth to children for one is no longer the person's concubine. It is a must according to the Yoruba belief that the two of them be allowed to continue with their love affair and get married emphasizing the fact that (enibátibímofúnnitikúronialèeni). However, if the male partner wants to play smart by rejecting the pregnancy, he will be asked by elders if truly he had sexual relationship with the female partner, if the answer is yes, he will be compelled to marry the lady and accept responsibility of the pregnancy. Sometimes, if the matter goes beyond normal, the family of the man will be compelled to take responsibility of the child after birth even though they may not take the mother of the child as wife.

The same is the case between husband and wife when they have disagreements in marriage and either of the party threatens to divorce or part ways with the other, elders in the family will call for a meeting to settle the differences amicably. In such gathering, they will make them remember the importance attached to children in the Yorubá society. No matter how hot the disagreement is, the moment the two parties ponder on what could befall their children if they part ways, they will give room for peaceful resolution in such matters with the belief that no one else can take good care of their children the same way they will. So, it is the belief in the Yoruba society that any relationship that produces children either in marriage or out of marriage so far children are involved has come to stay. The involvement of children automatically becomes a bound between the two parties.

Apart from the above mentioned point, every stage of child growth in the Yorubá thoughts and belief is characterized with different levels of care, handling and formative directives. One of the major beliefs that pertain to this fact is that a child not properly monitored and cared for will certainly become a social destitute when such child is expected to be productive. A societal destitute child cannot take good care of him/herself talk less of making good use of the legacies of his/her parents or family. Àlabí (2006: 127) attests to this with the submission that:

The Yoruba by nature are not indifferent to the public. This is because right from childhood, the public, society and the extended family play different roles in upbringing. This training is done in order to make sure that the family name is not dragged into the mud. 
A child that is denied proper upbringing or a child that refuses to yield to the common path of societal norms is regarded as good for nothing being. It is the responsibility of parents to guide and give formative instructions to their children, but this does not rest solely on them. It is also the responsibility of the extended family and the entire society by extension in playing this role. It is believed that only two people give birth to a child, but, the entire society guides and forms the child into the acceptable standard of their society.

Several mediums the Yoruba employ in caring and directing the children into the acceptable conduct of the society start from the cradle, such ways are oral poetry like poems, folktales, moonlight plays, folklores, among others. This mode of giving moral instructions is called moral or value systems (ìàomolúabí) Fálétí (2009). The traditional Yoruba society doesn't also spare the rod, they believe so much in the use of rod and simple scolding in correcting children when they misbehave.

The traditional Yorubá society engages more in farming and trading, it is also the responsibility of parents to inculcate in their children the virtue of hard work by introducing them to farming, trading or other forms of crafts they may choose to venture into, especially those family are known for hunting, blacksmith, tie and dye, weaving, hair dressing, drumming, and traditional medicine. It is a must for parents to give their children this form of education and economic empowerment so they can be financially independent at the appropriate time. In the contemporary Yorubá society, formal education and vocational training have largely taken the place of farming and trading to a large extent. Yorubá people frown at idle and unproductive members of their society and they believe that such people should not be tolerated. The Yoruba do everything possible to shake their children off such attitude so they could become better members of the society.

These days that civilization has taken root in Yoruba society, western education and foreign religions have improved greatly on children education with the introduction of religious education majorly in the Christian and Islamic form, education in the contemporary society has now translated to sound moral education, good value system, religious education and Western education. It is on these pillars that good moral base of the contemporary Yorubá society stands.

Yoruba philosophical belief on the importance of children also manifests when a married woman is faced with barrenness, which sometimes could cause separation. When a woman could not conceive on time, it do cause divers of problems, the reason is as a result of the place of prominence the Yoruba place having children over having a wife Ilésanmí (2004). They regard having children as a formidable platform on which their tomorrow stands. As a result, a woman that could not conceive or have children is faced with problems of having a stable home. Children are the support pillars women stand on in a Yoruba marriage. No matter how much devotion a barren woman gives to the marriage and her husband, when the husband dies, she will have nothing to inherit from the hus- 
band's properties. That is why the Yoruba believe that, children are the major belongings of the woman in marriage and at same time, the gain of marriage Oláiyá (2017: 670). Even if they do not opt for direct divorce of the woman, it will show in conduct and behavior that the woman no longer has regard from her husband's family. In some cases, elders do advice the couple to go separate ways for the woman to try another marriage if she will be lucky to have children. If the love the couple share is so strong and doesn't allow them to part ways, they will continue with the marriage but the message will be clear to the woman that she has overstayed her welcome and most importantly can't resist the husband from marrying another wife. The husband is free to have another wife that will bear children for him in such case. The barren wife will not also get disturbed by the action due to the belief that she could be lucky and have her prayers answered too if the new wife is able to conceive and have children. Ládéle and Fáníyi (1977). That is what the Yorubá mean with the belief that (oriomo ló ńpeomowáyé) Olájubù (1985).

In other times, when a woman is faced with challenges in her marriage, it could be that her husband is no longer showing enough care on her wellbeing. It could also be that she is being tormented by members of her in-laws, which must have reached climax of endurance. The woman may decide to file for a divorce or partial separation. Due to Yorubá philosophy on the importance of children, when she is advised and gives it a second thought, she will result to be more persevered and see the challenges as destiny or fate. Reason for this counsel is as a result of the importance placed on children in the Yoruba thoughts and belief system. She will eventually result to fate that she does not have husband but a father to her children Ládélé and Fáníyì (1977).

In conclusion, the struggles of the Yoruba on the welfare of their children are mainly for the betterment and sustenance of the Yoruba society, with emphasis on sustenance of the family name and good legacy. Apart from that, Yorubá people believe that it is only parents who leave behind morally, well to do and socially acceptable children to sustain their legacies after death that have children, that is why the Yorubá says "eniomọ sin lóbímo". They believe it is only such children that can sustain the good family name and legacies. Children that do not belong to this category they believe are mere societal problems that could subject the family name of little or no regard. That is why the Yoruba society does not believe in only having children, but having morally, socially and economically viable and empowered ones.

We observe that in the contemporary Yoruba society, there are noticeable changes that have bedazzled the long standing Yorubá beliefs system, most importantly on that of child birth, child upbringing and child education. Children's upkeep no longer occupy a prime place it used to occupy in the Yoruba traditional society due to the overbearing influence of civilization and unchecked or not well applied dictates of Western culture and education. Civilization, cultural clash (Yorubá culture with that of other nations, especially that of the Western 
world) and the overbearing influence of unchecked foreign religion on the Yorubá traditional religion have caused more of undesirable effects on the upbringing of children in the contemporary Yorubá society.

Many people of Yorubá extraction no longer pay adequate respect to marriage custom, talk less of having properly born and brought up children. Though, Western education has equally played very important role in the furtherance of child birth, child upbringing and child education, but also with attendant undesirable effects. Most teenagers no longer regard or yield to parents' and elders' instructions. Many parents too no longer have time for proper upbringing and education of their children. The types of occupations prevalent in the contemporary Yorubá society are not giving parents enough time for proper children upkeep. Babies these days spend more time with care givers than with their parents. They now spend longer hours at care given centers (crèche) as opposed to the type of care, attention and bound children enjoyed with their parents in the first three years of their lives. In such time in the past, Babies and toddlers enjoyed breastfeeding, which is scientifically proven that it enhances both physical and psychological growth of children. Many children these days are left in the mercies of house helps who sometimes have bad influence on them in several ways. House helps or care givers cannot give the same attention as the parents. There are little or less help care givers can give to children in terms of moral instruction, moral education and value orientation. Some parents do not allow outsiders to give formative instructions or mete corrective measures/punishments on their children, a situation which is at variance with the thoughts and beliefs of the Yoruba in such instance. The Yoruba belief is that two people give birth to a child, but the responsibility of making the child morally sound and fit for the society rests on the entire people of the society.

Some parents of this age even have carnal knowledge of their own children; some use them as sex workers, while some abuse them as slaves. They are less concerned about the future of such children, what matters to most parents of this age is monetary gain which is inimical to the Yoruba thoughts and beliefs. Many people even give birth to children more than what their financial capacity could cater for, while some use theirs for rituals and other nefarious activities.

Civilization has exposed many to sexual acts before marriage or without prospect for marriage which result in having children without fatherly or motherly care. This is far from the Yoruba belief on marriage and the place of prominence of children care. The male figure stands as the head in a family (marriage) while the female figure stands as the shoulder of support in a marriage. The two figures (father and mother) are indispensably dependent on each other for a workable marriage in the Yorùbá philosophy on marriage custom.

It should be noted however that this paper only detailed the Yoruba thoughts and beliefs on child birth and child moral upbringing in a cultural perspective. It has equally projected the Yoruba philosophy about the importance of marriage to having culturally acceptable children, the importance of children in Yorubá 
culture and various means the Yoruba society employ in conveying the message of its continuity to the children, parents, Yoruba society at large and the world in general. Several grounds still exist on the place and importance of children to the society left for extant scholars to research about for furtherance and betterment of the society. Such study will also serve the purpose of record keeping, mediation between the traditional and the contemporary society and to serve as archive in which ancient wisdom can be kept and sourced in other to shape the society and for the advancement of Yorubá culture, for it not to go extinct.

\section{Conclusion}

We have established that an inseparable relationship exists between culture and philosophy in the Yorubá society. We also established the Yorubá belief in childbirth and child moral upbringing. We argued that the overbearing influence of civilization and the unacceptable part of Western culture in the Yoruba society caused most of the inadequacies experienced in the contemporary Yorùbá society on the importance of childbirth and child moral upbringing, which in turn is the cause of most societal disorders of this time.

We advise that the present Yorubá society should look backwards and emulate the good virtues of the olden days by paying adequate attention to the upbringing of children and their education. This does not propose infringement on the rights of children, but should be done under the guidance of parents, the elderly and the society at large.

\section{Conflicts of Interest}

The authors declare no conflicts of interest regarding the publication of this paper.

\section{References}

Abímbọ́lá, W. (2006). ÀwonOjú Odù Mérẹèrìndínlógún. İbàdàn: University Press PLC.

Adébọwálé, M. A. (1999). Yorủbá Ethics and Metaphysics. Ògbómọsọ́: Yaloyn Publishing Venture Limited.

Adéoyè, C. L. (1979). Ásà àtil̀seYorùbá. İbàdàn: Oxford University Press.

Adétùgbó, A. (2001). African Continuities in the Diaspora. Lagos: Center for Black and African Arts and Civilization, National Theatre.

Àjayí, A. (2005). African Culture and Civilization. Ìbàdàn: Atlantis Books.

Àlàbí, M. (2006). Law Making in Pre-Colonia Yorùbá-Land. In T. Nínú Fálolá, \& A. Genova (Eds.), The Yoruba' in Transition (pp. 111-124). Durham: Carolina Academic Press.

Aládésanmí, O. A. (2012). Concept of Yorùbá Philosophy in Selected Yorùbá Novels: A Study in Literature and Philosophy. Unpublished $\mathrm{PhD}$ Thesis, Adó-Èkitì: Èkiti State University Adó-Èkitì.

Constitution of the Federal Republic of Nigeria.

Dáramọlá, O., \& Jejé, A. (1967). ÀwonÀsà àtiÒrịsaYorùbá Apá Kìn-ní-ní. İbàdàn: Oníbon-Ojé Press and Book Industries Nigeria Ltd. 
Devito, J. A. (2000). Human Communication: The Basic Course. New York: Longman Educational Publishers Inc.

Fádípè, N. A. (1970). The Sociology of the Yorùbá. İbàdàn: University Press.

Fálétí, A. (2009). Omolúabí: The Golden Attribute of a Yorùbáman. In P. O. Ogúndejì, \& A. Àkàngbé (Eds.), Omolúábí: Its Concept and Education in Yorủbáland (pp. 113-128). İbàdàn: İbàdàn Cultural Group.

Fálọlá, T. (2001). Culture and Customs of Nigeria. London: Greenwood Press.

Ilésanmí, T. M. (2004). Yorủbá Orature and Literature: A Cultural Analysis. Ilé-Ifẹ: Ọbáfémi Awólọwọ University Press Ltd.

İsọlá, A. (2010). Making Culture Memorable, Essays on Language, Culture and Development. İbàdàn: Hope Publications Ltd.

Johnson, S. (1921). The History of The Yorubá. Lagos: CSS Books Ltd.

Ládélé, T. A. A., \& Fáníyì, D. (1977). Ekúnİyàwó İbàdàn: Heinmann Educational Books (Nigeria) Ltd.

Ládélé, T. A. A., Oyèbámijí, M., Oyèdèmí, O., \& Ọlátúnbọsún, O. (2006). Akójopọ İwádìi Ijjinlè Àsà Yorủbá. İbàdàn: Gavima Press Ltd.

Obáfémi, O. (2012). Mysteries of God. Nashville, TN: Nelson Publisher.

Ògúnsínà, B. (2006). Sociology of the Yorùbá Novel: An Introduction. Ìlorin: Integrity Publication.

Ojó, E. T. (2013). A Stylistic Analysis of Proverbs in Selected Yorùbá Written Literature. PhD Thesis, İbàdàn: University of İbàdàn.

Ọlábímtán, A. (1987). Àkojọpọ İwádìi İjìnlè ẠsaYorùbá. Lagos: Macmillan Nigeria.

Ọláiyá, T. (2017). Childbirth, Childbearing and Child Education. In T. Fálolá, \& A. Akínyemí (Eds.), Culture and Customs of the Yoribá (pp 145-159).

Ọlájubù, O. (1985). İwé Àsà İbílè Yorùbá. Lagos: Longman Nigeria Limited.

Ọlátẹjú, A. (2016). İjajàgbara Àsà Yorùbá Nínú ÀwonÌwé İtànÀròsọ Fágúnwà. In O. Adébọwále, D. Adélékè, \& A. Adéjùmọ (Eds.), Òtunİmò nínú İtàn-Àroso D.O. Fágúnwà (pp. 208-217). Mankato: The Capstone Publications.

Ò̀pádọtun, O. (1998). Assàyànłlọ Onítàn. İbàdàn: Y-Books.

Oyèwálé (2016). Àgbéyẹwo Ọ̀rọ İfẹ àtil̀gbéyàwó Nínú Ạsàyàṅ̀é İtànÀròsọ Fágúnwà. In O. Adébọwále, D. Adélékè, \& A. Adéjùmọ (Eds.), Òtunİmọ nínú İtàn-Áròso D.O. Fágúnwà (pp. 246-260). Mankato: The Capstone Publications.

Oyèwálé, S. O. (2014). A Comparative Examination of Philosophical Themes in the Poetic Works of Olátúnbòsún Pládàpò and Ifáyemí Elébuìbon. $\mathrm{PhD}$ Thesis, Ìbàdàn: University of Ìbàdàn.

Täiwò (2017). Circumcision and Facial Marks. In T. Fálọlá, \& A. Akínyẹmí (Eds.), Culture and Customs of the Yoribá (pp 79-88).

Táiwò, A. (2014). İmọ İjìnlè ÈroYorùbá nínú Orin Saheedòsùpá. Unpublished.

The Constitution of Èkitì State (2002). 